\title{
Factors Influencing Spousal Role Reform and Purchase Decision in Nigeria: A Study of Consumable and Durable Goods
}

\author{
Sunny R. Igwe ${ }^{1} \&$ Bright ZorBari-Nwitambu ${ }^{2}$ \\ ${ }^{1}$ Marketing Department, University of Port Harcourt, Nigeria \\ ${ }^{2}$ Marketing Department, Ken Saro-Wiwa Polytechnic, Bori, Nigeria \\ Correspondence: Sunny R. Igwe, Marketing Department, University of Port Harcourt, Rivers State, Nigeria.
}

Received: September 20, 2018

Accepted: October 18, 2018 Online Published: November 24, 2018

doi:10.5539/ijms.v10n4p139

URL: https://doi.org/10.5539/ijms.v10n4p139

\begin{abstract}
The relationship between spousal role and purchase behavior is drawing more research attention especially with the rapidly changing lifestyles and demographics in cities. This paper investigated inter-spousal role on consumer purchase behavior of consumables and durable goods in Port Harcourt. Cluster sampling was carried out in Port Harcourt city and 95 spouses (medical doctors, nurses, and lecturers) were surveyed through the questionnaire instrument in Port Harcourt. Spearman rank correlation coefficient and multiple regression were adopted for the hypotheses testing. It revealed that socio-cultural characteristics, income, product idea, gender role orientation, level of involvement reforms significantly and positively influenced purchase decision of interspousal role while age had the least influence on the purchase decision. It concluded that a spouse who possesses these factor(s) affects the kind of purchase decision on durable and consumable goods. The study recommended that marketers should proactively identify, segment, position and develop marketing programs that appeal to a spouse who possesses and wades influence during purchase decision so as to secure sustained patronage.
\end{abstract}

Keywords: purchase decision, spousal role, consumable goods, gender orientation, Port Harcourt

\section{Introduction}

The rapid changing marital lifestyle, embracing of new gender orientation role and adoption of western culture is gradually replacing the role spouses play in African traditional buying behavior. The traditional family belief that one spouse (wife) should do most of the buying is becoming far from reality in most cities. Family buying and consumption decision in Nigeria and India are quite different from what obtains in Western world like the USA, Europe where purchase decision /consumption is done at the individual level, as such, the importance of family as a consuming and purchasing unit cannot be overlooked (Al-Azzam, 2014). Most studies have more emphasized on individual and organizational purchase behavior rather than family/ spouse purchase. Spouse's purchase behavior constitutes all behavioral patterns and intentions exhibited by couples (married partners) in the selection, purchase, usage, and disposal of goods, services, and ideas that satisfy family needs (Sheth, 2011; Kollat, Engel, \& Blackwell, 1970). The family represents people sharing affinity by blood, marriage, and law and living together (Al-Azzam, 2014). Spouses are conceptualized here as two persons that are joined together by law and/ or custom as husband and wife; excluding other forms of marriages and cohabitant e.g. lesbianism, gay marriage, unmarried partners living together in this context (Razzouk, Seits, \& Capo, 2007; Dhyani \& Agarwal, 2014). Spouse does not exhibit the same amount of dominance and influence in the purchase decision. The role each spouse plays and what accounts for this role change is worth explaining in purchase decision in the Nigerian environment. Marital power is the potential ability of a spouse to wade a higher influence on the behavior of the other during family decision making (Bartley, Blanton, \& Gilliard, 2005).

No doubt, as observable in most Nigeria homes, spouses face daily conflicts on purchase decision as to who initiates, influences and finally decides on what brand type, and which retail outlet to purchase, when and for whom these brands are to be actually purchased. These conflicts have multiplier effects which affect our social order, firm's sustained patronage, and national development. In purchase decision making, families make either joint or independent, autonomous decisions based on individualism and collectivism (Razzouk, Seits, \& Capo, 2007), but the worry here is to understand what factors actually help to influence spouse's ability to arrive at a purchase decision. The spousal decision is becoming more and more complex due to brand proliferation, cyber 
information search, time constraint, gender role dynamism, income changes and the nature of product involved. In traditional Nigerian, it is common to see wives dominate in purchase decisions of consumables like brands of toothpaste; men dominate in highly durable goods like furniture, home appliances, and electronics. Decisions regarding children's education, kids' savings accounts, are jointly taken. These divergent choices and opinions on product selection, purchase, usage, and disposal open for more worry as to what account for this joint, single, autonomous decision of spouse (Hanzaee \& Lotfizadeh, 2011).

Inter-spousal role influences in consumer purchase decisions have been variedly investigated by authors in different Western economies given the economic importance of household to national development and marketing performance (Al-Azzam, 2014; Altekar \& Keskar, 2014; Durmaz, 2014; Lotfizadeh, 2013; Polya \& Szucs, 2013; Penz \& Kirchler, 2012; Sidin et al., 2004), and unveiled mixed findings and in-exhaustive factors. For instance, Hanzaee and Lotfizadeh (2011) found changes in the behavioral orientations of husbands and wives. Guo (2011) found several factors that influence consumption and purchase behavior are internal as income, gender, age, education. While, Barles-Arizon et al. (2003) found that age of couple, income, number of years of cohabitation, sex role orientation, couples level of socialization influence spousal purchase conflict resolution tactics. In Nigeria, few and scarce studies were done on spouse and purchase decision, for instance, Opara and Uboegbulam (2015) on the empirical study of the family purchase decision for durable goods, their purchase decision was conceptualized as a decision-making process, need recognition, information search, and purchase decision. They carried out statistical difference analysis and found out that husband influence in the purchase process is more at need recognition stage. Similarly, Omodafe (2015) studied determinants of children's role in family buying decision-making: The case of South-South. And unveiled that a positive relationship exists between perceived joint (parents and children) level of involvement in buying decision and some demographic profiles

However, scarce studies have investigated the spousal role on the actual purchase decision, especially incorporating socio-cultural / religious and level of involvement as this study intends to add. Nigerians are highly religious and very cultural people. Socio-cultural/ religious is conceptualized as group influence, belief, practices, values about couple power relation transmitted and shared from generation to generation (Durmaz, 2014). We agree with (Altekar \& Keskar, 2014) and conceptualized level of involvement as personal interest and level of individual participation in decision and evaluation in making process. Again, the Nigerian spouse differs greatly from of the Western economies in their family purchase decisions and approach to information dissemination on product purchase and use. Thus, the aim of this paper is to investigate factors influencing spousal role reform on purchase decisions and what accounts for changes in purchase decisions between couples. In this study, we identify new reform factors like a spouse's income, age, gender role orientation, and purchase idea, especially level of involvement and cultural/ religious characteristics.

\section{Literature Review}

\subsection{Theoretical Foundation}

The baseline theory is anchored on family system theory, the theory of Household production and household system theory.

Family system theory or Bowen theory posits that the spouse is best understood as a part of his/ her family than when acting or thinking in isolation from one another, and that the family is an emotional and social unit with other members who are emotionally connected one to another (Kerr, 2000). This believes that one's spouse emotional attachment influences the entire family wellbeing and decision.

Household Production Theory basically considers how spouses produce, consume, and allocate time, energy and money in relation to the acquisition of standard of living and their underlying influence. Gary Becker, Kelvin Lancaster, and Richard Muth propounded the household theory. The theory identified an increase in the number of married women's involvement and participation in labor-force and how they allocate their time within the household to produce those commodities they need (Heckman, 2015). Household production theory holds that consumers' choice of a product is not particularly tied to the functioning of the product as they are purchased directly from the market, but the transformation of such commodity into goods they value through a household production function.

Of more relevance is the household system theory which anchors that there are multiple influences: social-cultural, political, economic, demographic factors that influence the role of spouses in consumption situations. From decades past (Davis, 1976; Burns, 1977; Webster, 1995; Reiss \& Webster, 1997) to recent time (Barles-Arizon, Fraj-Andres, \& Martinez-Salinas, 2013; Kancheva \& Marinov, 2014; Zitkiene, Markeviciute, \& Mickeviciene, 2017), studies on how husbands and wives influence purchase decisions and their relative roles in the family purchase decision process have been of great interest to behaviourists due to the significant number of 
family household units compared to single households in the society (Hanzaee \& Lotfizadeh, 2011). Family purchase decisions are mostly characterized by joint or group decisions and can be quite complex and challenging due to conflicts that often arise from differences in spouse power and role structures. Spousal purchase conflict involves perceived divergent interest among couples and feeling of fear or satisfaction with a particular purchase decision, and the worry that the other spouse will not be favored with the outcome of such decision (Dhyani \& Agarwal, 2014). These factors are conceptualized in the framework and discussed below.

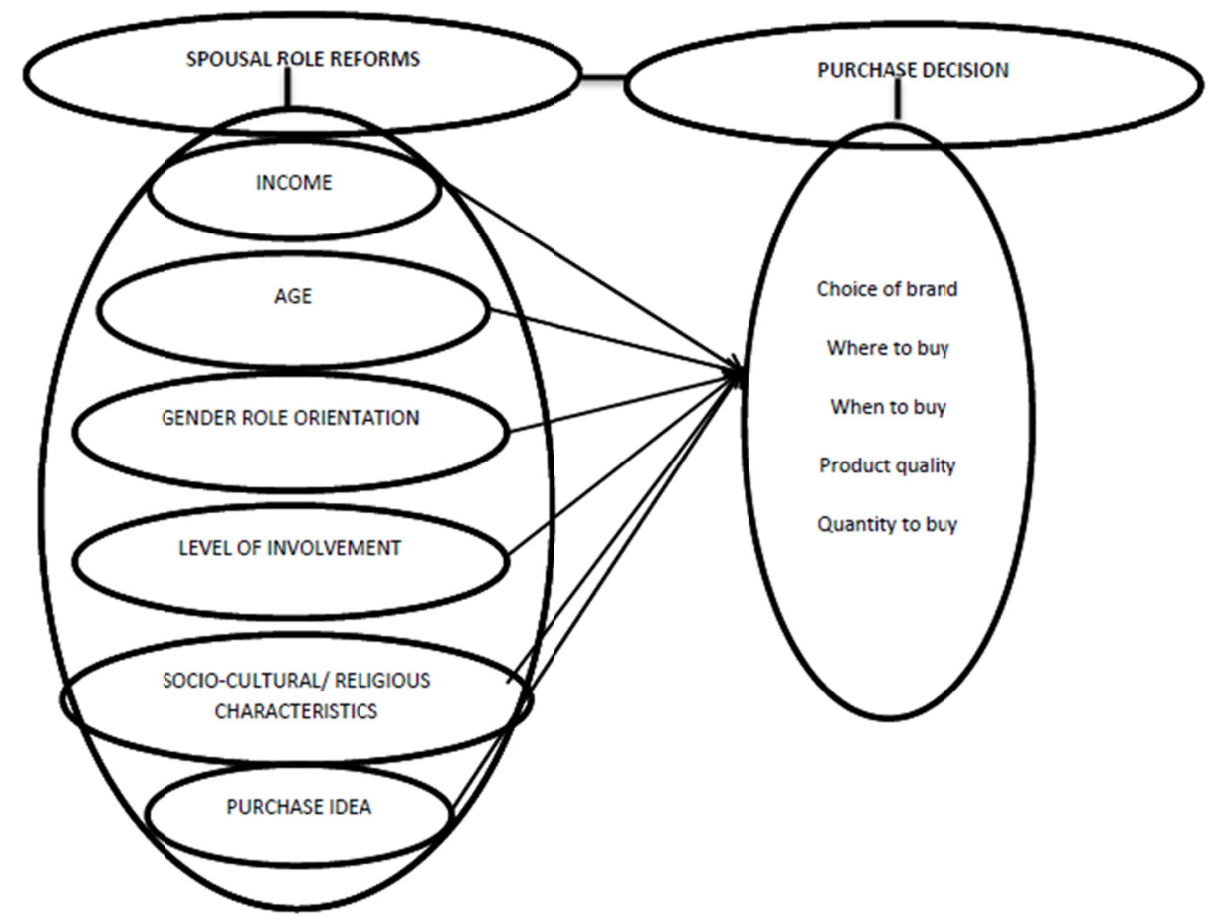

Figure 1. The conceptual model of inter-spousal role influence on purchase decision for national development

In the family decision-making process, no spousal decision is exclusively dominant. The steps and processes involved in family purchase decision making as a social unit and core driver of the economy are of keen interest to marketing and advertising strategists (Thangasamy \& Patikar, 2014).These factors are explained;

\subsection{Income Variation}

Family decision making theories empower a spouse with a higher income bracket to renege his/her individual opinion during the decision-making process (Barnett \& Stum, 2013). If there is a perceived clear income difference and the major contribution to family expenditure, the spouse making such higher contribution tends to influence and dominate in the purchase decision. Spouse income is measured as an amount of discretionary, net, disposal and inherited wealth influence a spouse posssses during purchase decision (Kancheva \& Marinov, 2014). The increasing rate of women's employment status, income, inherited wealth and wife family background have given wives more purchasing power in the family and have posed a profound influence on their orientation towards purchase decisions within the family setting (Dhyani \& Agarwal, 2014). Studies have shown that an individual's power to make decisions emanates from his/her financial earning and contribution (Lotfizadeh, 2013; Kang \& Lee, 2015). It can be adduced in the hypothesis that spouse amount of income contributed during family expenditure may influence his/her dominance in a purchase decision.

\subsection{Age Difference}

Age is a contextual factor that comes into play when making purchase decisions in the family (Barnett \& Stum, 2013). Absolute and relative age differences between spouses affect who dominates the decision process. Traditionally in most marriages, the wife is always younger and is subject to the decision of the husband. Perceived age difference contributes to spouse respect and reverence, which further influence spousal dominance in decision making. Studies have shown that age has a significant influence on interspousal purchase decisions. In some cases, conflicts may arise if the wife (who perhaps is younger than the husband) feels that the husband plays presumed decision making role whereby the husband solely assumes the decision roles and yet make it 
look like such decision was jointly agreed upon (Burns, 1977). In purchase conflict resolution in families, decision making and consumption experiences are often joint and have a shared influence among spouses regardless of age (Barles-Arizon, Fraj-Andres, \& Martinez-Salinas, 2013). We hypothesize that spouse age variation will influence who dominates in the purchase decision

\subsection{Gender Role Orientation}

Gender role orientation refers to the value, teaching, norms, and mindset that are inculcated about gender inequalities among married couples (Sidin, Zawawi, Yee, Busu, \& Hamzah, 2004). Numerous studies reveal that sex role orientation causes conflict in interspousal purchase decision-making process (Kancheva \& Marinov, 2014; Reiss \& Webster, 1997; Webster, 1995). Couples seek to make decisions that minimize conflict through emotional evaluation in the decision-making process (Barnett \& Stum, 2013) and employing conflict resolution techniques such as politicking, joint decision, social pressure and political bargaining that help achieve desired purchase decision. Socially/ culturally given, some gender predominate in a certain purchase decision, e.g. rarely in Ikwerre ethnic group a husband goes to buy foodstuffs in the open market, it is culturally reserved for the wives. Though, there is highly gender role dynamism in our present-day life. Changing gender role of women which include women fully employed in the factory work, becoming chief executives, in politics, and in professional bodies have made women tilt towards autonomous purchase decision, as opposed to the earlier men dominated decision-making style decades ago (Hanzaee \& Lotfizadeh, 2011; Davis, 1976). Wives are by tradition the initial, greatest purchase influencers in the family, and more involved in influence stage and actual family purchase decisions (Kancheva \& Marinov, 2014). However, Iakshmi, Niharika \& Lahari (2017) have argued that women are more sensitive, warm and apprehensive than the opposite sex, and often experience contextual changes in terms of location, religious and socio-cultural factors that surround the purchase at a given time. Thus, a hypothesis is raised that spouse role orientation influence purchase decision.

\subsection{Level of Involvement}

Involvement refers to the degree of personal relevance, participation and/or interest caused by a stimulus in a specific situation (Kang \& Lee, 2015). It involves personal interest, time dedication, and personal participation, and willingness to accept decision outcome in the decision-making process (Burns, 1977). A spouse will be interested in making decisions on products with which he/she is highly involved, interested or will personally use, and or greatly affect his future wellbeing. Products that are of huge financial outlay, risky and irreversible decision to a spouse require individual high-level involvement. Studies show that some purchase decisions are even taken by their children that are less dominating or influencing the decision. The degree of involvement also affects purchase evaluation process and time(Altekar \& Keskar, 2014).Spouse household structure, which measures the number of children, relations and other family members living together with the couple may also affect the degree of involvement in decision making (Barnett \& Stum, 2013; Martensen \& Gronholdt, 2008). Consequently, Liang (2012) studied the correlation of product involvement with product knowledge and found out that a consumer will be more knowledgeable about a product he/ she is highly involved with and this will, in turn, influence his/ her decision-making ability. The new paradigm in family consumption pattern is the collaborative consumption measured as the degree to which couples consider their relationship as constituting a team and joint, rather than two separate individuals with selfish and egoistic aims (Kang \& Lee, 2015; Zitkiene, Markeviciute, \& Mickeviciene, 2017). Arising from the extant review, we assert that spouse level of involvement has the propensity to influence one's purchase decision

\subsection{Socio-Cultural/ Religious Characteristics}

An understanding of people's culture, belief, norms values, and religious teaching, and rituals that influence spouses' roles in the decision-making process is very essential (Lotfizadeh, 2013). Some belief empowers certain gender and spouses the right to take a certain decision (Lotfizadeh, 2013). Cultural influence refers to the traditional or modern norms of the people that shape the decision making ability of couples. Cultural values, myths, values, respect, taboo and sanctions, customs, rituals, and laws, are transmitted from generation to generation that makes each cultural group distinct from the other (Durmaz, 2014), and this tends to shape and mould spouses' ability to take a decision in purchase time. In times past, most culture regarded the wives as a man's property that should be kept at home alongside his other properties, not allowed to make decisions concerning the purchase of durable goods, though, a new women liberalism and dynamism have given more rights to women (Polya, 2013). Couple's social connections, sanction, and fear of anti-group behavior, peer affinity and pressure, and social reference group a spouse belongs to shape and provide certain right to a decision (Al-Azzam, 2014). From this mixed arguments then, we posit and assert that a spouse who is indoctrinated into socio-cultural / religious activities will be influenced to have more dominance in a purchase decision 


\subsection{Purchase Idea/ Information}

Knowledge is power. Product knowledge refers to the amount of knowledge and information an individual possesses about a product's/ brand's feature during evaluation, decision and usage situations (Kang \& Lee, 2015). Spouse exposure to, or pre-informed to buying process occasioned by usual information of product availability, characteristics, performance and prices are crucial on who finally makes the purchase decision. The amount of purchase idea reduces dissonances and ascribes purchase decision power to the spouse who has such information (Kang \& Lee, 2015) and helps to reduce inter-spousal purchase conflict. Spousal intimacy and sharing of ideas and using communication tactics to modify spouse is helpful in enriching product information (Barles-Arizon, Fraj-Andres, \& Martinez-Salinas, 2013). Purchase decision process involves thinking and discussing purchase characteristics, attributes and values, ideas and purchase decisions between spouses. The information search process depends on the type of product. Couples generally seek information in order to address a purchase problem from the pre-purchase stage through purchase stage, and to the post-purchase stage. Couples compare, make a joint decision and affirm their information on decision making to ensure they arrive at the best decisions (Kang \& Lee, 2015). We are inclined to hypothesize that spouse with more product information will dominate the purchase decision.

\subsection{Purchase Decision}

The purchase decision is a critical stage in the consumer decision-making process. It entails the actual choice of marketing $\mathrm{P}(\mathrm{s})$. The behavior of the consumer as regards to buying, using and disposing of a product have been of interest to marketers. Purchase behavior is conceptualized here as decisions regarding choice of brand, where to buy (purchase location and outlet) when to buy (time of purchase), and amount/quantity to buy and more intriguing is whether to continue the use of a brand. Spouses use evaluative criteria like social approval, brand/ outlet attributes, color, price, quality, store location, advertising, brand image, performance, style, and overall product appearance to guide decision making (Al-Azzam, 2014). Each of these decisions, often are either wife or husband dominated. Husband is more dominated to take a decision on "where to buy" and choice of brand in durable goods while a scrutiny on "how much it costs" is often the concern of the wife. Often, spouse plays complimentary/ joint decision role in decision especially when the decision exhibit time, place exigencies and role congruence, their gender characteristics (Kang \& Lee, 2015). Male shoppers lay much emphasis on speed, convenience, and efficiency when buying a product, while female shoppers concentrate more on pricing, cleanliness, and quality (Chopra, 2014). Nowadays, shopping changes have seen more men involve infrequently and freely in grocery shopping like their traditionally women-dominated shopping (Chopra, 2014). The right spousal purchase decision has a significant influence on economic independence, national development, and strategy outcome (Tertilt, 2006; Samimi \& Jenatabadi, 2014).

\section{Study's Hypotheses}

$\mathrm{Ho}_{1}$ : Spouse income significantly influences the purchase decision of durable and consumable goods.

$\mathrm{Ho}_{2}$ : Spouse gender role orientation significantly influences the purchase decision of durable and consumable goods.

$\mathrm{Ho}_{3}$ : Spouse age significantly influences the purchase decision of durable and consumable goods.

$\mathrm{Ho}_{4}$ : Spouse level of involvement influence purchase decision of durable and consumable goods.

$\mathrm{Ho}_{5}$ : spouse purchase idea significantly relates with purchase decision of durable and consumable goods.

$\mathrm{Ho}_{6}$ : Spouse Socio-cultural/ religious characteristics significantly influenced purchase decision of durable and consumable goods.

\section{Method}

Study of this nature entails survey design. A cluster survey was conducted on staff quarters of three educated professional bodies in Port Harcourt. A convenience sample of 120 copies of questionnaires was administered to staff residing only in government-owned quarters. Each household was given two copies of the questionnaire. Out of which, 95 respondents completed and returned theirs questionnaire instrument comprising 11 medical doctors, 24 nurses and 60 lecturers residing in Dina Denni-Fiberesima Doctors quarters (formerly Braithwaite Memorial Specialist Hospital), nurses' quarters and staff/Lecturer's quarters of Rivers State University in Port Harcourt. cross-sectional surveyed.

In measuring and validating the constructs, extant literature was adapted from works and scale of (Barlés-Arizón, et al., 2013; Kang \& Lee, 2015; Barnett \& Stum, 2013); Kancheva and Marinov (2014) with little modification. The scale specifically considered gender orientation as - more women in workforce, breadwinner, hour/ time 
spent in office rather than with spouse (Sidin, Zawawi, Yee, Busu, \& Hamzah, 2004). Product idea/information was measured as full knowledge of product attribute, performance, comparative price, usage, availability, and alternative brand. Income was measured as the amount of income earned for family expenditure, willingness to singularly carter and bring extra income for a budget, and income difference with a spouse. Level of involvement indicators is personal participation, decision acceptance and delegation, decision time, and busy schedule of a spouse. Purchase decision was measured on who finally decides on brand choice, outlet choice, when, and quantity choice purchase decision to discontinue the use of a brand.

The study examined the factors influencing interspousal role in purchase behavior of consumables such as toothpaste, soap and perfumes; and durables such as electrical appliances, furniture, children education funding, and kid's saving accounts of the above respondents. Spearman rank correlation coefficient was used to test the individual hypothesis $\mathrm{Ho}_{1-6}$ while multiple regression was to confirm the total explained variation caused by the study variables. SPSS 20.0 software aided the analysis. The 5 Likert type scale ranging from strongly agree to strongly disagree and assigned 1-5 value respectively was used

\section{Data Analysis}

\subsection{Demographic Analysis}

Table 1. Demographic analysis

\begin{tabular}{|c|c|c|c|c|c|}
\hline & & Frequency & Percent & Valid Percent & Cumulative Percent \\
\hline \multicolumn{6}{|c|}{ Respondent's Age } \\
\hline \multirow{6}{*}{ Valid } & $25-30 \mathrm{yrs}$ & 7 & 7.4 & 7.4 & 7.4 \\
\hline & $31-35 y r s$ & 14 & 14.7 & 14.7 & 22.1 \\
\hline & $36-40 y r s$ & 18 & 19.0 & 19.0 & 41.1 \\
\hline & $41-45 y r s$ & 23 & 24.2 & 24.2 & 65.3 \\
\hline & $45 y r s+$ & 33 & 34.7 & 34.7 & 100.0 \\
\hline & Total & 95 & 100.0 & 100.0 & \\
\hline \multicolumn{6}{|c|}{ Gender } \\
\hline \multirow{3}{*}{ Valid } & Male & 55 & 57.9 & 57.9 & 57.9 \\
\hline & Female & 40 & 42.1 & 42.1 & 100.0 \\
\hline & Total & 95 & 100.0 & 100.0 & \\
\hline \multicolumn{6}{|c|}{ Occupation } \\
\hline \multirow{4}{*}{ Valid } & Doctor & 11 & 11.58 & 11.58 & 11.58 \\
\hline & Nurse & 24 & 25.26 & 25.26 & 36.84 \\
\hline & Lecturers & 60 & 63.16 & 63.16 & 100.0 \\
\hline & Total & 95 & 100.0 & 100.0 & \\
\hline \multicolumn{6}{|c|}{ Family size } \\
\hline \multirow{5}{*}{ Valid } & 2 persons & 6 & 6.3 & 6.3 & 6.3 \\
\hline & 3-5 persons & 34 & 35.8 & 35.8 & 42.1 \\
\hline & 6-8persons & 48 & 50.5 & 50.5 & 92.6 \\
\hline & 8-10persons & 7 & 7.4 & 7.4 & 100.0 \\
\hline & Total & 95 & 100.0 & 100.0 & \\
\hline
\end{tabular}

Source: Research Data, 2018.

Tables 1 above presents the age of the respondents: 7 respondents with $7.4 \%$ fall within 25 -30years age bracket; 14 respondents with $14.7 \%$ fall within $31-35$ years; 18 respondents forming $19.0 \%$ of the population are between 36 to 40 years; while 23 respondents with $24.2 \%$ are between $41-45$ years; and finally, 33 respondents with $34.7 \%$ of the population are above 45 years old. The result revealed that a higher number of respondents residing at these quarters are 45 years and above and they have shown adequate sufficient buying experience by their age brackets

On gender in table 1, 58 male respondents accounting for $61.1 \%$ of the study population and 37 female respondents with $38.9 \%$ proportion of the study, which means both spouses (wives and husbands) are fully represented and suitable for the analysis

On occupation in table 1, a total of 95 respondents were studied out of which 11 are medical doctors forming $11.58 \%$ of the study population, while 24 are nurses representing $25.26 \%$ of the study population, and 60 lecturers with $63.16 \%$ of the study's population. This shows a full representation of all the educated profession 
studied

Table 1 on family size above revealed the various family sizes studied: they include 6 families of 2 persons which comprise both spouses with no children constituting $6.3 \%$ of the study's population; 34 households of 3-5 persons consisting of spouses and 1-3 children forming $35.8 \%$ of the population; 48 households of 6-8 persons is made up of spouses and 4 to 6 children with 50.5\%; and finally, 7 families of $8-10$ persons comprising spouses and $6-8$ children forming $7.4 \%$ of the study's population. This means that majority of the respondents have larger family structure and make a purchase decision to sustain the family.

\subsection{Correlation Analysis}

Table 2. Correlation

\begin{tabular}{|c|c|c|c|c|c|c|c|c|}
\hline & & income & age & $\begin{array}{l}\text { gender role } \\
\text { orientation }\end{array}$ & $\begin{array}{l}\text { level of } \\
\text { involvement }\end{array}$ & $\begin{array}{l}\text { sociocultural / } \\
\text { religious } \\
\text { characteristics }\end{array}$ & $\begin{array}{l}\text { purchase } \\
\text { idea }\end{array}$ & $\begin{array}{l}\text { consumer } \\
\text { purchase } \\
\text { behavior }\end{array}$ \\
\hline \multirow[t]{3}{*}{ income } & sig. (2-tailed) & .000 & .000 & .000 & .000 & .000 & .000 & .000 \\
\hline & $\mathrm{n}$ & 95 & 95 & 95 & 95 & 95 & 95 & 95 \\
\hline & Pearson correlation & 1 & $.971^{* *}$ & $.922^{* *}$ & $.835^{* *}$ & $.962^{* *}$ & $.911^{* *}$ & $.897^{* *}$ \\
\hline \multirow[t]{2}{*}{ age } & sig. (2-tailed) & .000 & .000 & .000 & .000 & .000 & .000 & .000 \\
\hline & Pearson correlation & $.971^{* *}$ & 1 & $.964^{* *}$ & $.929^{* *}$ & $.790^{* *}$ & $817^{* *}$ & $.839^{* *}$ \\
\hline \multirow{3}{*}{$\begin{array}{l}\text { gender role } \\
\text { orientation }\end{array}$} & sig. (2-tailed) & .000 & .000 & .000 & .000 & .000 & .000 & .000 \\
\hline & $\mathrm{n}$ & 95 & 95 & 95 & 95 & 95 & 95 & 95 \\
\hline & Pearson correlation & $.922^{* *}$ & $.964^{* *}$ & 1 & $.870^{* *}$ & $.983^{* *}$ & $.943^{* *}$ & $.911^{* *}$ \\
\hline \multirow[t]{2}{*}{ level of involvement } & sig. (2-tailed) & .000 & .000 & .000 & .000 & .000 & .000 & .000 \\
\hline & Pearson correlation & $.835^{* *}$ & $.929^{* *}$ & $.870^{* *}$ & 1 & $.941^{* *}$ & $.796^{* *}$ & $.985^{* *}$ \\
\hline \multirow{3}{*}{$\begin{array}{l}\text { sociocultura / } \\
\text { religious } \\
\text { characteristics }\end{array}$} & sig. (2-tailed) & .000 & .000 & .000 & .000 & .000 & .000 & .000 \\
\hline & $\mathrm{n}$ & 95 & 95 & 95 & 95 & 95 & 95 & 95 \\
\hline & Pearson correlation & $.962^{* *}$ & $.790^{* *}$ & $.983^{* *}$ & $.941^{* *}$ & 1 & $.983^{* *}$ & .992 \\
\hline \multirow[t]{3}{*}{ purchase idea } & sig. (2-tailed) & .000 & .000 & .000 & .000 & .000 & .000 & .000 \\
\hline & $\mathrm{n}$ & 95 & 95 & 95 & 95 & 95 & 95 & 95 \\
\hline & Pearson correlation & $.911^{* *}$ & $.817^{* *}$ & $.943^{* *}$ & $.796^{* *}$ & $.983^{* *}$ & 1 & $.928^{* *}$ \\
\hline \multirow{3}{*}{$\begin{array}{l}\text { consumer purchase } \\
\text { decision }\end{array}$} & sig. (2-tailed) & .000 & .000 & .000 & .000 & .000 & .000 & .000 \\
\hline & $\mathrm{n}$ & 95 & 95 & 95 & 95 & 95 & 95 & 95 \\
\hline & Pearson correlation & $.897^{* *}$ & $.839^{* *}$ & $.911^{* *}$ & $.985^{* *}$ & $.992^{* *}$ & $.928^{* *}$ & 1 \\
\hline
\end{tabular}

\footnotetext{
${ }^{* *}$ Correlation is significant at the 0.05 level (2-tailed).
}

Source: Research SPSS output Data, 2018.

In table 2 above, the result of hypothesis one, correlation analysis revealed that income and spouse purchase behavior have a significant and positive correlation coefficient of $0.897^{* *}$ and the p-value less than 0.05 alpha. Meaning that $89.7 \%$ change in interspousal purchase behavior is caused by income.

Also, the result as presented in the correlation table shows that age and spouse purchase decision have significant positive $0.839^{* *}$ correlation at the p-value less than 0.05 alpha. This implies that age disparity of spouse influences consumer purchase behavior by $83.9 \%$.

The table 2 above revealed that gender role orientation and spouse purchase decision have a significant and positive correlation coefficient of $0.911^{* *}$ and the p-value less than 0.05 alpha The implication is that $91.1 \%$ influence on consumer purchase decision can be attributed to inter-spousal gender role orientation.

In correlation analysis table 2 that level of involvement and spouse purchase decision is significant, positive correlated at $0.985^{* *}$ and the p-value less than 0.05 alpha meaning that $98.5 \%$ change in consumer purchase decision is explained by the inter-spousal level of involvement.

Furthermore, the correlation coefficient of socio-cultural/ religious characteristics and spouse purchase decision was examined and the result as presented in table 2 above shows that a correlation coefficient of $0.992 * *$ and 
p-value less than 0.05 alpha exist between both variables, which means a $99.2 \%$ change in consumer purchase decision caused by socio-cultural/ religious characteristics.in

In table 2, the outcome of the correlation revealed that purchase idea and consumer purchase decision have $0.928^{* *}$ correlation coefficient and the p-value less than 0.05 alpha. This implies that $92.8 \%$ change in consumer purchase decision is caused by purchase idea. In conclusion, it was revealed from the outcome of the table that all the studied variables were strongly significant at 0.000 (2-tailed).

\subsection{Multiple Regression Analysis}

Table 3. Model summary

\begin{tabular}{lllll}
\hline Model & $\mathrm{R}$ & R Square & Adjusted R Square & $\begin{array}{l}\text { Std. The error of the } \\
\text { Estimate }\end{array}$ \\
\hline 1 & $.912^{* *}$ & $.874^{* *}$ & $.862^{* *}$ & $.697^{* *}$ \\
\hline
\end{tabular}

a. predictors: (constant), Income, Age, Gender role orientation, Level of involvement, sociocultural/religious characteristics, Purchase idea.

In table 3, multiple regression analysis was conducted and from the outcome of Table 2 above, the $\mathrm{R}=0.912$ indicating a strong positive relationship between all elements of the predictor variable (income, age, gender role orientation, level of involvement, socio-cultural /religious characteristics, purchase idea) and the criterion variable - purchase decision. The $\mathrm{R}^{2}=0.874$ indicates that $87.4 \%$ variation spouse purchase decision is accounted for by the multiple influences of all elements of the predictor variable while $(100-87.4) \%=12.6 \%$ is not explained by the study variables

Table 4. ANOVA ${ }^{\mathrm{a}}$

\begin{tabular}{llllll}
\hline Model & Sum of Squares & Df & Mean Square & F & Sig \\
\hline Regression & 2734.406 & 2 & 1326.734 & 1798.683 & $.000^{\mathrm{b}}$ \\
$\begin{array}{l}\text { Residual } \\
\text { Total }\end{array}$ & 126.723 & 107 & .896 & & \\
\hline
\end{tabular}

a. Dependent variable: Purchase decision.

b. Predictors: (constant), Income, Age, Gender role orientation, Level of involvement, Sociocultural Religious Characteristics, Purchase idea.

Furthermore, table 4 showed ANOVA analysis of the regression of 2734.406 and a residual of 126.723 that the study could not account for, indicating a good model fit, sig level of 0.00 less than $0.05 \mathrm{p}$-value.

Table 5. Coefficients ${ }^{\text {a }}$

\begin{tabular}{|c|c|c|c|c|c|}
\hline \multirow{3}{*}{ Model } & \multicolumn{2}{|c|}{ Unstandardized coefficients } & \multicolumn{2}{|l|}{ Standardized } & \multirow{3}{*}{ Sig. } \\
\hline & & & Coefficients & $\mathrm{t}$ & \\
\hline & $\mathrm{B}$ & Std. Error & Beta & & \\
\hline (Constant) & .143 & .507 & & .298 & .847 \\
\hline Income & 1.460 & .087 & .976 & 14.578 & .000 \\
\hline Age & 1.157 & .104 & .924 & 11.318 & .000 \\
\hline 1 Gender Role Orientation & 1.573 & .108 & 892 & 12.831 & .000 \\
\hline Level of Involvement & 1.290 & .099 & .955 & 10.798 & .000 \\
\hline \multicolumn{6}{|l|}{ Sociocultural/Religious } \\
\hline Characteristics & 1.165 & .124 & .767 & 11.823 & .000 \\
\hline Purchase Idea & 1.134 & .097 & .907 & 10.119 & .000 \\
\hline
\end{tabular}

a. Dependent variable: Purchase decision.

b. Predictors: (constant), Income, Age, Gender role orientation, Level of involvement, Sociocultural Religious Characteristics, Purchase idea.

In table 5 above, the coefficient of the standard show all the variables was significant at 0.000 (2-tailed significance) revealing that there is a significant relationship between studied variables and purchase decision. Consequent upon this all earlier stated hypotheses were accepted. 


\section{Discussion of Findings}

Unlike previous studies in Nigeria (Opara \& Uboebulam 2015; Umodafe, 2015), our focus has been to determine factor influencing spousal role on purchase decision and to especially evaluate how spouse's (income, age, product idea/ information, and more novel constructs like cultural /religious and level of involvement help influence spousal purchase decision. All the six (6) hypotheses $\mathrm{Ho}_{1-6}$ were accepted and supported that:

Inter-spousal income significantly influences purchase decision was supported and accepted.

Inter-spousal age significantly influences purchase decision was supported and accepted.

Inter-spousal gender role orientation significantly influence purchase decision was supported and accepted

Inter-spousal level of involvement significantly influence purchase decision was supported and accepted

Inter-spousal purchase idea significantly influence the purchase decision

Inter-spousal Socio-cultural/ religious characteristics significantly influence purchase decision was supported and accepted.

This new finding agrees and collaborates with previous findings of Bartley, Blanton, and Gilliard (2005); Kang \& Lee (2015); Barnett \& Stum (2013); Kancheva and Marinov (2014) that spouse internal and external factors like income, age, product ideal, gender role orientation were instrumental in accounting which spouse wades influence during purchase decision. Our finding appeared so with the possibility that the respondent's demographics surveyed revealed all as working class, educated and knowledgeable professionals and who live in urban cities and are not retirees.

Again our two novel constructs; the level of involvement and socio-cultural/ religious factors were positive, significant and supported. This also concurs with works of recent findings (Zitkiene, Markeviciute, \& Mickeviciene, 2017; Al-Azzam, 2014) that spouse level of social and personal involvement affect the purchase decision. Our finding became positive with the contextual fact that most Nigerians are more religious people and are cultural bond is their activities. Also, there is a high-level of social approval and influence existing within this study group.

\section{Conclusions}

1) The study concluded that the studied variables pose a significant influence on interspousal purchase behavior. And that spouse income age, product idea, gender role orientation, socio-cultural /religious and level of involvement affect inter-spousal chances to take and dominate in the final purchase decision

2) Couples' sociocultural and religious belief influence to a great extent purchase decisions among spouses (i.e. couples consider the impact of a certain purchase decision on their social status and their religious background before taking such decision).

3) The study further concludes that although all the variables under study have a significant correlation value, couples' age was the least determining factor that influenced purchase decision making among them.

4) Purchase decisions on fast moving consumer goods like toothpaste involved little or no inter-spousal conflicts compared to durable goods.

\section{Recommendations}

Based on the foregone the study recommends that;

1) Marketers involved in the promotion and sale of consumer goods should take a critical look at the study variables that are capable of promoting interspousal purchase intentions among couples.

2) Marketing programmes and product decisions should be in consonance with the sociocultural norms and religious belief of couples.

3) Marketers should regularly provide constant product ideal and information in adverts as this would encourage couples to get involved in purchase decisions quickly on joint decision outcomes.

4) Manufacturers of consumable and durable goods should identify, develop, segment, position, and target along spouse who wades influence during the purchase of durable good consumables, and kids' education investment.

\section{Limitation}

Hardly any piece of work is not constrained. This work is constrained by the fact that it was more of a correlation study of factors that influence the spouse role in the purchase decision. It totally neglected to use a 
more robust statistical test to show how each of these factors accounts for wives/ husbands dominant in purchase decision by using ANOVA, MANOVA, the discriminant analysis in each of consumer and durable goods. Also, this study is limited by demographic profile - tribe, religion and education were not considered and analyzed against product categories. The scope implied a limitation as the study only centered in Port Harcourt city of Nigeria and very few occupations. This calls for more research attention.

\section{Acknowledgments}

The valuable contributions of the reviewers and editors are appreciated. The critics and suggestions from participants of 2018 National Conference of Faculty of Management Sciences, University of Port Harcourt is recommendable.

\section{References}

Al-Azzam, A. F. M. (2014). Evaluating the effect of social factors affecting consumer behavior in purchasing home furnishing products in Jordan. British Journal of Marketing Studies, 2(7), 80-94.

Altekar, S., \& Keskar, A. (2014). A study of the factors impacting the buying decision process vis-à-vis specified consumer durables in NOIDA. Journal of General Management Research, 1(2), 111-123.

Barlés-Arizón, M. J., Fraj-Andrés, E., \& Martínez-Salinas, E. (2013). Purchase decision-making in the couple: conflict-solving tactics. International Journal of Business and Social Science, 4(6), 28-43.

Barnett, A, E., \& Stum, M, S. (2013). Spousal decision making and long-term care insurance. Journal of Financial Counselling and Planning, 24(2).

Bartley, S. J., Blanton, P. W., \& Gilliard, J. L. (2005). Husbands and wives in dual-earner marriages: decision making, gender role attitudes, the division of household labor, and equity. Marriage and Family Review, 37(4), 69-94. https://doi.org/10.1300/J002v37n04_05

Burns, A. C. (1977). Husband and wife purchase decision-making roles: agreed, presumed, conceded, and disputed. Advances in Consumer Research, 4, 50-55.

Chopra, A. N. (2014). Factors affecting purchase behavior of women grocery consumer: an insight. Journal of Business Management \& Social Sciences Research (JBM\&SSR), 3(6), 71-79.

Davis, H. L. (1976). Decision making within the household. Journal of Consumer Research, 2(4), 241-260. https://doi.org/10.1086/208639

Dhyani, A., \& Agarwal, A. (2014). Dynamics and conflict of spousal purchase decision: a review study. International Journal of Research in Business Management, 2(6), 27-38.

Durmaz, Y. (2014). The Influence of Cultural Factors on Consumer Buying Behaviour and an Application in Turkey. Global Journal of Management and Business Research: E-Marketing, 14(1), 1-10.

Guo, L. (2011). A research on influencing factors of consumer purchasing behaviors in cyberspace. International Journal of Marketing Studies, 3(3), 182-188. https://doi.org/10.5539/ijms.v3n3p182

Hanzaee, K. H., \& Lotfizadeh, F. (2011). Influence of family structure on consumer decision-making style in Iran. International Journal of Business and Management, 6(11), 297-304. https://doi.org/10.5539/ijbm.v6n11p297

Heckman, J. J. (2015). Introduction to a theory of the allocation of time by Gary Becker. The Economic Journal, 125(March), 403-409. https://doi.org/10.1111/ecoj.12228

Lakshmi, V., Niharika, D. A., \& Lahari, G. (2017). Impact of gender role on consumer purchasing behavior. IOSR Journal of Business and Management, 19(8), 33-36.

Kancheva, I., \& Marinov, G. (2014). Perceptions of marital roles in basic commodity groups purchase decision-making. Annales Universitatis Apulensis Series Oeconomica, 16(1), 156-161.

Kang, J., \& Lee, Y.-J. (2015). Does apparel purchase involve joint purchase decision-making?: Interpersonal influences between spouse or significant others. Journal of the Korean Society of Clothing and Textiles, 39(6), 799-811. https://doi.org/10.5850/JKSCT.2015.39.6.799

Kerr, M. E. (2000). One family story: a primer on Bowen theory. The Bowen Center for the study of the family. Retrieved from http://www.thebowencenter.org

Kollat, D. T., Blackwell, R. D., \& Engel, J. F. (1970). Research on consumer behavior. Holt, Rinehart and Winston marketing series. 
Liang, Y.-P. (2012). The relationship between consumer product involvement, product knowledge, and impulsive buying behavior. Procedia- Social and Behavioral Sciences, 57, 325-330. https://doi.org/10.1016/j.sbspro.2012.09.1193

Lotfizadeh, F. (2013). Religion and family structure: two factors affecting consumer decision making styles in Iran. International Journal of Management and Business Research, 3(2), 107-119.

Martensen, A., \& Gronholdt, L. (2008). Children's influence on family decision making. Innovative Marketing, $4(4), 14-22$.

Omodafe, U. P. (2015). Determinants of children's role in family buying decision-making: The case of south-south, Nigeria. International Journal of Management Science and Business Administration, 1(7), 30-38. https://doi.org/10.18775/ijmsba.1849-5664-5419.2014.17.1003

Opara, B. C., \& Uboegbulam, G. C. (2015). The empirical study of the family purchase decision for durable goods: The Nigeria experience. International Journal of Arts \& Sciences, 8(4), 219-228.

Penz, E., \& Kirchler, E. (2012). Sex-role specialization in a transforming market: empirical evidence from Vietnamese middle-class households. Journal of Macromarketing, 32(1), 61-73. https://doi.org/10.1177/0276146711421787

Polya, E., \& Szucs, R. S. (2013). Examining the role of family members in the family buying center in the adult Hungarian population. European Scientific Journal, 9(19).

Razzouk, N., Seitz, V., \& Capo, K. P. (2007). A comparison of consumer decision-making behavior of married and cohabiting couples. Journal of Consumer Marketing, 24(5), 264-274. https://doi.org/10.1108/07363760710773085

Reiss, M. C., \& Webster, C. (1997). Relative influence in purchase decision making: married, cohabitating, and homosexual couples. Advances in Consumer Research, 24, 42-47.

Samimi, P., \& Jenatabadi, H. S. (2014). Globalization and economic growth: empirical evidence on the role of complementarities. PLoS ONE, 9(4), e87824. https://doi.org/10.1371/journal.pone.0087824

Sheth, J. (2011). Models of buyer behavior. Marketing Classic Press.

Sidin, S. M., Zawawi, D., Yee, W. F., Busu, R., \& Hamzah, Z. L. (2004). The effects of sex role orientation on family purchase decision making in Malaysia. Journal of Consumer Marketing, 21(6), 381-390.

Tertilt, Michele (2006). Polygyny, women's rights, and development. Journal of European Economic Association $4(2-3), 523-530$.

Thangasamy, E., \& Patikar, G. (2014). Factors influencing consumer buying behavior: a case study. Global Journal of Management and Business Research: E-Marketing, 14(5), 1-10.

Webster, C. (1995). Determinants of marital power in decision making. Advances in Consumer Research, 22, 717-722.

Zitkiene, R., Markeviciute, G., \& Mickeviciene, M. (2017). Factors influencing consumer behavior and decision to use smart technologies. Perspectives of Business and Entrepreneurship Development in Digital Age, 20-22 September, 135-143 Brno, Czech Republic.

\section{Copyrights}

Copyright for this article is retained by the author, with first publication rights granted to the journal.

This is an open-access article distributed under the terms and conditions of the Creative Commons Attribution license (http://creativecommons.org/licenses/by/4.0/). 